\title{
Linguistic Analysis of George Bernard Shaw's “Pygmalion”
}

\author{
George Mathew Nalliveettil *
}

Department of Humanities and Sciences, Vignana Bharathi Institute of Technology, Hyderabad, Telangana, India

DOI: $10.36348 /$ sijll.2020.v03i04.004 $\quad$ | Received: 02.04.2020 | Accepted: 09.04.2020 | Published: 22.04 .2020

*Corresponding author: George Mathew Nalliveettil

\section{Abstract}

Communicative activities in ESL/EFL classroom contexts are productive when relevant linguistic devices are applied to literary texts. The literary effectiveness of George Bernard Shaw's "Pygmalion", an early twentieth-century play has been widely appreciated for its linguistic and literary effectiveness. The dialogic structures composed in the actions of the play reveal the varieties of spoken forms of English present during the Victorian period. After thorough scrutiny of the available research papers related to "Pygmalion" on the web, this study addressed the issues that were given less importance by the earlier studies. Considering the significance of "Pygmalion" as a prescribed coursebook in various universities across the world, this paper analysed the dialogic language of the play from a linguistic perspective. The existing literature on Pygmalion provides insights into thematic analysis from a literary and socio-linguistic perspective, referring to the class struggles and feminism. This paper examined the dialogues from a linguistic perspective. Weigand's [1] dialogic principles were applied to the utterances of the characters, thereby providing insights into the metalinguistic aspects. The paper also presents the semantic effect of the communicative exchanges that the characters engage in when they meet at different settings in the play. Also, it provides resourceful ideas to the ESL/EFL teachers on various linguistic aspects that need to be focused while teaching a literary text. The findings of the study reveal the dialogic forms in "Pygmalion" can be useful to enhance the verbal, non-verbal and written communication of ESL/EFL students.

Keywords: Pygmalion, Linguistic, Analysis, Play, Dialogic, Communicative, Language.

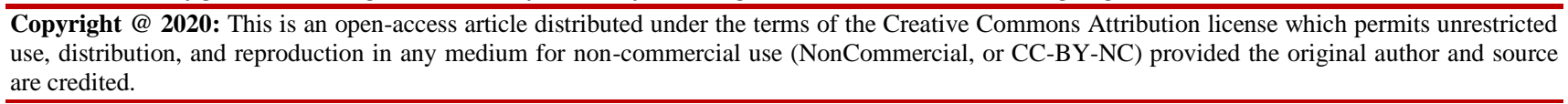

\section{INTRODUCTION}

In the $21^{\text {st }}$ century, many varieties of English are spoken across the world. Moreover, the availability of vast web resources in audio-visuals and written form gave impetus to the non-native speakers of English to listen to different varieties of English as well as access variety of written texts. In recent years, even though volumes of books are being produced in the areas of functional English and Literature and made available to the public in the form of print and electronic versions, the books that were written by eminent writers during $19^{\text {th }}$ and $20^{\text {th }}$ centuries are still prevalent in universities across the world.

The intensity of emotions and reasoning in George Bernard Shaw's plays draws the attention of current generation readers and students of literature to appreciate the dialogues between the characters. His skill in scripting sixty plays during his career as a playwright makes him be one of the prominent playwrights of the Victorian period. George Bernard Shaw (1856 - 1950) portrayed the life of British middle-class society during the Victorian period. In
1952, he won a noble prize in literature and the Oscar award for best writing and screenplay of 'Pygmalion.' The underlying meaning of linguistic structures in the dialogic exchanges between the characters of 'Pygmalion' reveals Bernard Shaw's skilful use of language to communicate feelings, emotions, frustrations, failures, humour and success of the middleclass society of England during the Victorian era. In the 'Preface to Pygmalion', Bernard Shaw draws the attention of the readers to "German and Spanish" in comparison to the English. He highlights the deteriorating situation of English not being accessible to Englishman. The emotional discourse through which he communicates sets the tone to make his argument for a 'phonetic enthusiast' more acceptable to the readers. In Bernard Shaw's view

"The reformer England needs today is an energetic phonetic enthusiast: that is why I have made such a one the hero of a popular play. There have been heroes of that kind crying in the wilderness for many years past." (P.7, Shaw, 2018) 
In the above lines, Bernard Shaw tries to convince the readers that the "the reformer England" needs someone who can refine the English of Englishmen, thus rationalising his argument for "an energetic phonetic enthusiast", and being critical to those phoneticians who ruined their reputations due to arrogance. The diction through which Shaw introduces the need for a speech analyst rather than an economic reformist clarifies his stance for introducing the character Higgins as his mouthpiece in 'Pygmalion'. The choice of vocabulary and the sequencing of dialogic language indicate Shaw's effective use of linguistic devices to communicate the language spoken by people from different walks of life. Aiming to transform the English society through country's intellectual life, Shaw became an active force behind Fabian society, middle-class socialist group, thus becoming a theatre critic to displace the artificialities and hypocrisies of the Victorian stage [16].

\section{REVIEW OF LITERATURE}

In Bernard Shaw's plays, the dialogic language scripted at a metalinguistic level portrays the realities of the society during the Victorian period. A review of the current research published on George Bernard Shaw's Pygmalion discusses class struggle, pronunciation patterns, thematic analysis and stylistic patterns. Mayer, L. R. (n.d.)[15] points out that Pygmalion discusses societal problems and the treatment of language in education during the Victorian period. According to Anugerahwati [2], Pygmalion, in particular, is a book of sociolinguistics because one can learn the culture and social situations prevailing in London. From the feminist perspective, Pygmalion is viewed as a reflection of the oppressions that women experience in a male-dominated society. Lihua [3] approaches Pygmalion from a feministic perspective and highlights that Eliza's improper English pronunciation is due to a weak economic and social position in society. Cherlin and Abilasha [4] believe that George Bernard Shaw's Pygmalion draws the readers attention to social class and feministic Perspectives. Reynolds [5] points out that though Shaw's career choice was not playwriting, he could secure a permanent place among the British playwrights due to Pygmalion. Reynolds points out that even though Shaw calls for attention to the importance of phonetics through Pygmalion, but it remains unclear whether people realised the relevance of studying phonetics. Gadhiraju [6], analyses Pygmalion through the characters of Dolittles and highlights the concept of class struggle in British society during the Victorian age. Xiaowei [7] approaches Pygmalion from a feministic perspective and points out that the character Eliza is a perfect model for the lost modern female, and these lost females can draw lessons from the play and achieve the great transformation to win independence, esteem and freedom. In Pygmalion, George Bernard Shaw used an ancient classical myth to explore social problems that lasted through time, and the actions of the play reveal the transformation of a poor and ignorant girl into an aristocratic and cultured society [8]. Gallardo [9] applied the concepts of critical discourse analysis to Pygmalion and stated that the character Higgins who views that passion to the perfect use of language as a condition for one's success uses social power to impose his point of view to make the character Eliza accept and live under his instructions. Jemeena and Shenbagapriya [10] point out that the central theme of Pygmalion is emotion. They think that Bernard Shaw's anti-sentimental theories forced him to end the play in an unromantic atmosphere. Hamoud [11] applied multiple techniques such as Bernstein's principles of relating language and social class to analyse the phonological and syntactical perspectives in Pygmalion as well as Grice's conversational principles to analyze Eliza's speech, Hamoud concludes that Bernard Shaw used language as a medium to convey social aspects of the Victorian era indirectly.

In the past, many researchers discussed the contributions and achievements of George Bernard Shaw, highlighting the rewards bestowed for his literary excellence in the form of plays. Many critics also believe that Shaw used characters as a mouthpiece to vent out his sarcasm of the Victorian society. Considering Pygmalion as one of the Bernard Shaw's masterpieces, there are also universities across the world which prescribe "Pygmalion" as the main course book for drama studies in their undergraduate or postgraduate curriculum related to English language and literature. The composition of syntactic structures in the dialogic form can also be read for language development. It will be a useful classroom resource for the enhancement of spoken and written discourse of ESL (English as a Second Language) students. The playwright's creativity in the composition of syntactic structures and its semantic interpretations calls upon the attention of the linguists as well as non-linguists to examine the dialogic exchanges.

A review of the past research in the analysis of Bernard Shaw's Pygmalion suggests that most of the researchers presented thematic and literary aspects. However, not many studies have been carried out on linguistic aspects of the play. This paper draws attention to the linguistic elements that the playwright applies to create the intended communicative effect to appreciate the dialogic language and its relevance in the teachinglearning of English in ESL classrooms. In order to make linguistic analysis relevant, the dialogic principles outlined by Weigand [1] were found useful. Weigand's [1] principles were applied by Nalliveettil and Gadallah [12] to analyse the dialogic discourse of Tennessee Williams' 'The Glass Menagerie'. The present study examines the linguistic aspects of Bernard Shaw's 'Pygmalion'. 


\section{RESEARCH QUESTIONS}

The present study applies Weigand [1] principles of dialogic language to address the following:

a) The effectiveness of dialogic discourse to perform communicative functions such as verbal and non-verbal acts.

b) How the playwright connects the dialogic actions of the play and makes it understandable to the readers

c) How to explore the linguistic aspects of dialogic language

d) The suitability of syntactic structures in the dialogues to enhance English language skills of ESL/EFL students.

\section{Limitations of the Data Analysis}

George Bernard Shaw's Pygmalion is a drama with a Preface followed by Five Acts and a Sequel. Since each of the five acts constitutes of dialogic structures potential for diverse interpretations and grammatical categorisation and could result in exhaustive data, this study is limited to selective dialogic structures. This paper applied the theoretical approach of Weigand [1] to analyse linguistic aspects of the dialogic language of Pygmalion.

\section{Description of the Data}

The primary source of data for the current study is the dialogic exchanges between the characters in George Bernard Shaw's 'Pygmalion', an early $20^{\text {th }}$ century British drama. For data analysis, specific dialogic exchanges from the drama are presented in its original form. The play was set at the end of the Victorian period, and the dialogic exchanges between the characters reveal different aspects of social life in England. It is a five-act-play with a preface and sequel. The significant characters in the play are Professor Henry Higgins, Colonel Hugh Pickering, Eliza Doolittle, Alfred P. Doolittle, Mrs Pearce, Mrs Higgins and Freddy Eynsford-Hill. In the sourcebook, the names of the characters are given in capital letters, so the same procedure is followed when referring to the characters in data analysis and the discussion section. The source for data analysis and interpretation for this article are extracts quoted in its original form that is a re-printed version of Pygmalion by Shaw [13]. The dialogues are analysed based on the dialogic principles outlined by Weigand [1].

\section{Application of Weigand's [1] theory for data analysis}

Weigand [1] in Language as a Dialogue (S.Feller. Ed.) proposed relevant principles such as dialogic and action principle for dialogic analysis. According to her, the speech acts are mutually dependent because they perform communicative functions such as initiative or reactive. In Bernard Shaw's 'Pygmalion', a study of the dialogic exchanges between the characters highlights the different aspects of language use to fulfil the communicative purpose of either making an initiation or a reactive move which leads to the progression in the sequence of actions. Dialogues between the characters are not just confined to thematic analysis but has the potential to enrich the readers due to its metalinguistic eloquence. The present study follows the theoretical framework suggested by Weigand [1] to analyse the exchanges between the characters in Bernard Shaw's 'Pygmalion'.

\section{DATA ANALYSIS \\ Initiative and Reactive Speech Acts}

In Act I of the play, Shaw conceals the real names of the characters and introduce them to the readers as "THE MOTHER", "THE DAUGHTER", "THE FLOWER GIRL". He reveals the social identity and economic background of the characters. The familiarity of the roles and responsibilities of a mother and a daughter makes the dialogic language acceptable to the readers. The choice of a specific communication style in a given situation often depends on the familiarity or strangeness between the individuals. Feller [14] points out that Weigand based her theory on the initiative speech act and the reactive speech act, which are considered to be functionally two different types of action. According to feller, the initiative speech act makes a pragmatic claim, while the reactive act is expected to fulfil that claim. In Pygmalion, the initiative and the reactive speech acts between the interlocutors reveal the variations in the English language use during the Victorian era. The utterances of the interlocutors provide clues to the readers of the existence of cockney and Standard English. In Act 1, the interlocutors are found interacting with each other amid heavy summer rain.

\section{Datum, ACT I}

THE MOTHER. I heard you call him by it. Dont try to deceive me.

THE FLOWER GIRL [protesting] Who's trying to deceive you? I called him Freddy or Charlie same as you might yourself if you was talking to a stranger and wished to be pleasant.

(Shaw, 2018, ACT 1 P. 16)

The dialogic discourse between the characters reveals the heightened curiosity of THE MOTHER to probe into the relationship of her son with THE FLOWER GIRL. The utterance 'young gentleman's name' communicates THE MOTHER's tone of revealing her son as someone who is polite and educated in spite of his earlier impolite act of knocking the basket of THE FLOWER GIRL, leading to the scattering of the flowers on the ground, thus prompting a protest from THE FLOWER GIRL. THE MOTHER seems to be more concerned with the reactive move of THE FLOWER GIRL addressing her son as 'Freddy'. THE MOTHER's initiative to accept 'Freddy' as her son sparks a reactive move from THE FLOWER GIRL. THE MOTHER's curiosity to know how THE FLOWER GIRL knew her son's name as 'Freddy' 
compels her to make the next move of shedding sixpence and buy flowers from THE FLOWER GIRL. The playwright highlights how the colloquial language, if not understood by the listener, can be a source of suspicion in a given communicative situation. In the utterance of THE FLOWER GIRL, the playwright intentionally scripts the utterance "if you was talking", referring to the grammatical inaccuracy of the usage of the verb 'was' instead of 'were'. The initiative and reactive moves of the interlocutors fulfil the playwright's goal to inform the readers about the linguistic variations in the language use of different interlocutors that he will be discussing in the progression of the play.

\section{Speech act and cognition}

According to Weigand [1], a playwright has to use language and create situationally appropriate utterance forms. She points out that the communicative structures a playwright composes in the form of dialogues should trigger a cognitive response from the readers. Weigand [1] says that the dialogues often fall into a particular sentence type because the playwright manipulates the structures to make it appear dialogic and connect the actions of the play to the cognitive abilities of the readers. In the 'Preface to Pygmalion', George Bernard Shaw makes a satiric reference to the contributions of his contemporary phonetician, Henry Sweet, and states that in the third act of the play "the postcards which Mrs. Higgins describes are such as I have received from Sweet[13]". In Act III of Pygmalion, Mrs. Higgins is heard saying to her son, Mr. Higgins, "though I like to get pretty postcards in your patent shorthand, I always have to read the copies in ordinary writing you so thoughtfully send me." [13]. Through these dialogic actions, Shaw depicts the mean attitude of phoneticians during his generation who used phonetic scripts for the purpose of correspondence. It is quite ironic that even the educated class finds challenging to decipher the phonetic scripts, so they preferred to read messages that are composed using letters of the English alphabet.

In Act 1, Bernard Shaw initially conceals the name of the main character Prof. Higgins and introduces him as a note-taker. The playwright provides a picturesque view of the momentary actions that the characters enact in their interactions. In Act 1, contextual clues in square brackets '[overbearing but good-humored]' provides additional information to the readers about the temperament of THE NOTE TAKER, thereby, linking the non-verbal gestures of the interlocutor to the thought process of the readers.

\section{Datum, ACT I}

THE NOTE TAKER [overbearing but good-humored] Oh, shut up, shut up. Do I look like a policeman?

THE FLOWER GIRL [far from reassured] Then what did you take down my words for? How do I know whether you took me down right? You just shew me what youve wrote about me. [The note taker opens his book and holds it steadily under her nose, though the pressure of the mob trying to read it over his shoulders would upset a weaker man]. Whats that? That aint proper writing. I cant read that.

(Shaw, 2018, ACT 1, P. 19)

The utterance, 'shut up', though considered to be an ill-tempered response the contextual clues of nonverbal elements about the voice of THE NOTE TAKER provides the background knowledge to the readers about the tone of the utterance. The behaviour of THE NOTE TAKER to make notes of the utterances of THE FLOWER GIRL leads to a verbal conflict between the two interlocutors. The utterance "my words" (standard form) signifying the ownership of specific structures that THE FLOWER GIRL already produced and later revealed by THE NOTE TAKER as "Cheer ap, Keptin; n' haw ya flahr orf a pore gel" (cockney) is an evidence of the existence of standard as well as cockney varieties during the Victorian era. An analysis of the dialogic language in Act 1 of Pygmalion indicates variations in the utterances of THE FLOWER GIRL. The composing of cockney into the dialogues of THE FLOWER GIRL serves the playwright's intentions to reveal that the demographic background as a reason for such a variety while on the other hand the utterances of THE FLOWER GIRL that comply with the rules of standard English is probably intended to make the actions of the drama comprehensible to the readers.

\section{Expression and Meaning}

According to Weigand [1], a language expression has the potential to be used differently by a speaker and listener due to differences in cognitive abilities such as thinking, perception, knowledge, judgment. Weigand points out that the phrases "with great seriousness" and "with high seriousness" is an example of the difference in usage rather than a difference in meaning. She believes that the rules which operate on these set of expressions facilitate its use by the principle of free choice. In Act 1, Bernard Shaw introduces the main characters of the play and progresses to Act II, where Eliza decides to take English lessons from Higgins to fulfil her dream of being employed as a lady in a flower shop. Claiming Eliza as his daughter, DOLITTLE insists on interacting with Higgins. However, Higgins is surprised to learn about the arrival of DOLITTLE and enquires how he came to know about the presence of Eliza.

Datum, ACT II

HIGGINS: Then how did you know she was here? DOOLITTLE ["most musical, most melancholy"] I'll tell you, Governor, if you'll only let me get a word in. I'm willing to tell you. I'm wanting to tell you. I'm waiting to tell you.

(Shaw, 2018, ACT II, P. 53-54) 
The structures such as "I'm willing to tell you. I'm wanting to tell you. I'm waiting to tell you" reveal the playwright's creativity to integrate poetic temperament into dialogic language. The insertion of the word "native" to the utterance "woodnotes wild" denotes to a specific reference to a vernacular dialect spoken in slum dwellings. The expressions "natural gift of rhetoric" and "sentimental rhetoric" conveys the linguistic ability of DOLITTLE to influence others and hide his real self. The initial usage of the word "rhetoric' after a preposition "of" gives a different meaning as compared to the phrase "sentimental rhetoric". However, these expressions have a synonymous relationship because a person who has the natural talent of being rhetoric can manipulate his skills to influence others. Further, the readers are informed that a linguist can identify "mendacity and dishonesty" of an individual through his/her speech.

\section{Discourse and Coherence}

Weigand [1] is of the opinion that in a speakerlistener communicative situation, the habits of an individual can be open points where misunderstanding occurs. She points out that due to individual variation in the cognitive background, understanding between interlocutors will be very difficult. However, coherence can be achieved when these open points can be immediately corrected through the 'cooperative attempt to understand'. Weigand clarifies that cooperative attempt does not refer to the literal meaning of a sentence, but it is to understand the meaning of an utterance in the context of dialogic interaction, i.e., its communicative function and proposition. In Act III of Pygmalion, the character HIGGINS is keen to examine the effectiveness of the pronunciation lessons given to ELIZA. In order to test her competence in conversation, HIGGINS requests his mother, Mrs HIGGINS, to provide a platform for Eliza to communicate with a group of people who can speak the language proficiently.

\section{Datum, ACT III}

HIGGINS. I must. Ive a job for you. A phonetic job. MRS. HIGGINS. No use, dear. I'm sorry; but I cant get round your vowels; and though I like to get pretty postcards in your patent shorthand, I always have to read the copies in ordinary writing you so thoughtfully send me.

(Shaw, 2018, ACT III, P. 68)

In Act III, the playwright introduces MRS HIGGINS scolding her son, HIGGINS, for intruding as an unwanted guest during her leisure hours at home. However, HIGGINS clarifies that "I've a job for you. A phonetic job" and MRS HIGGINS reacts to the literary meaning of the utterance and expresses her inability to take up the offer due to her past experiences with HIGGINS. Mrs HIGGINS interpretation of the utterance "A phonetic job" contradicts with HIGGINS's viewpoint because MRS HIGGINS thinks that she does not have the required competence to assist HIGGINS in his professional endeavours as a phonetician. In order to make "a cooperative attempt" to make the interlocutors understand each other, the playwright progresses to compose dialogic utterances such as "I've picked up a girl", "some girl has picked you up?" and "I don't mean a love affair". The poetic diction in the utterances "picked up" (past tense) and "picked you up?" (criticize/correcting the behaviour), differentiating the intended meaning makes the dialogic language more effective. These utterances also create awareness to the readers of its usage in different communicative contexts.

\section{Utterance and communicative purpose}

According to Weigand [1], the utterances can be classified as direct, indirect, or idiomatic speech acts but these speech acts are functionally not identical but differ according to how they convey the communicative purpose. The literal meaning of the sentence uttered is realised in the direct speech act, while the indirect speech act applies the inferencing process to understand the meaning. Weigand points out that the literal meaning of an utterance gets blocked in idiomatic speech act because the meaning is realised in the whole sentence. The communicative functions of these speech acts can be understood only when a listener or a reader brings in a certain amount of expert knowledge required to comprehend the utterance or a text.

In Act 4, the playwright's creative composition of dialogic language to intensify the emotional disturbances of the interlocutors into a physical conflict achieves the intended result because the characters are found exchanging the discourse of anger, frustration, dominance and disillusionment. The playwright's effectiveness to portray non-verbal language in square brackets creates an impact to the dialogic actions because the non-verbal actions guide the readers to create visual images to either empathize or criticise the attitude of the interlocutors. The intensity of the nonverbal cues given below indicates how the readers go beyond the literary meaning to make inferences.

Datum, ACT IV

HIGGINS [looking at her in cool wonder] The creature IS nervous, after all.

LIZA [gives a suffocated scream of fury, and instinctively darts her nails at his face]!!

HIGGINS [catching her wrists] Ah! would you? Claws in, you cat. How dare you show your temper to me? Sit down and be quiet. [He throws her roughly into the easy-chair].

(Shaw, 2018, ACT IV, P. 96)

The above dialogic exchanges between the characters are a progression from a reaction of Higgins to the unusual behavioural response of LIZA hurling slippers at him. The playwright intentionally deviates from the syntactic rules to capitalize "IS" to inform the 
readers of the tone of voice and making that specific utterance to be heard at a louder voice to signal that the interlocutor is referring to the present state of mind of LIZA. The usage of the word "creature" by HIGGINS, comparing the actions of LIZA to that of an animal further hurts her feelings. The playwright portrays the reactionary move of LIZA with exclamation marks "!!"”. The composition of the structure "Claws in, you cat" reminds the readers of sharpness of ELIZA's nails and the intensity of the injury or bruises and the physical pain that HIGGINS has already undergone. The initial usage of "creature" further connects with "cat" to make the actions of ELIZA appear beastly.

\section{Integrating competence and performance}

Weigand [1] believes that human beings ability to speak integrates with other abilities such as perceiving and thinking and so they are aware that they have to distinguish between what is said and what individual social beings mean in particular contexts. She points out that human beings possess an extraordinary human ability called "competence-inperformance" and the cultural environment partly shapes it and partly determined by human nature. Weigand says that the central reference point of competence-in-performance are human beings and their purposes, interests, abilities and also comprises of all parameters that influence human actions such as human nature and intentions.

The dialogic exchanges between the characters reveal how communication styles of individuals influence the listeners to change their attitudes. In the conversation, Liza reminds Pickering of his respectful attitude while addressing her and reveals that the expression "Miss Doolittle" made her feel good and praises him for his mannerisms.

\section{Datum, ACT V}

LIZA [continuing] It was just like learning to dance in the fashionable way: there was nothing more than that in it. But do you know what began my real education?

\section{PICKERING. What?}

LIZA [stopping her work for a moment] Your calling me Miss Doolittle that day when I first came to Wimpole Street. That was the beginning of self-respect for me. [She resumes her stitching]. And there were a hundred little things you never noticed, because they came naturally to you. Things about standing up and taking off your hat and opening doors-

(Shaw, [1] ACT V, P. 117)

The dialogic language though is a reference to the attitude of PICKERING towards LIZA, also differentiates HIGGINS' competence in phonetics and his personality traits. The playwright highlights that though HIGGINS is competent with the spoken English skills, his personality traits seem to be an obstacle in interpersonal communication. However, PICKERING is found to be competent as well as good-mannered because of which LIZA learns to lead a civilized life under intolerable conditions of HIGGINS. In the play, Bernard Shaw initially portrays LIZA as a flower girl who earns her living by selling flowers in the streets. However, on the other hand, HIGGINS is depicted as a phonetician from an academic community. The communication styles and personality traits of each of these two characters hailing from different cultural environments often lead to conflicting situations with either of the interlocutors, finding it challenging to accommodate the social nature of each other. Though LIZA cooperates to improve her competence in spoken English, she often rebukes HIGGINS for his personality traits of not respecting her feelings and for treating her like a machine. On the other hand, LIZA appreciates PICKERING for addressing her as "Miss Doolittle" and for "a hundred little things" that helped her to mould social mannerisms needed for a civilised society. The playwright also sheds light on the importance of integrating verbal as well as non-verbal communication in enhancing human relations.

\section{Language use and Misunderstanding}

Weigand [1] points out that it is not only by understanding each other's language that human beings understand one other, but they also use different ways to come to an understanding because language use accepts misunderstanding as well. The interlocutors can overcome misunderstanding because they can correlate as well as negotiate their interests, tasks and positions. Weigand opines that through the process of clarifying difficulties, they correct their misunderstandings and non-understanding.

Act $\mathrm{V}$ is a revelation of the sequence of events leading to the disappearance of LIZA from HIGGINS's house. Further, the playwright highlights the transformation of DOLITTLE from a slum-dweller to a respectable position. DOLITTLE is however found to be unhappy of his current social status as he finds it as an obstacle for his personal space and so criticises HIGGINS for elevating him to a higher social stature. Amid LIZA's disappearance from HIGGINS's house in Act 5, the playwright shifts reader's attention to DOLITTLE. The dialogic interaction in which LIZA and HIGGINS are found to have unpleasant verbal exchanges at the end of Act IV makes the readers be in a state of suspense about the actions that might follow in Act V.

As the readers progress to Act $\mathrm{V}$, they are expected to infer from the lines of dialogic language about LIZA's disappearance from HIGGINS's house. At the beginning of Act 5, the playwright depicts the appearance of HIGGINS at Mrs Higgins's house, telephoning the police and later conveying to MRS HIGGINS's about LIZA's sudden escape from HIGGINS's house. In order to make the actions of the 
play realistic and appealing, the playwright aptly relates the sequences of the play from LIZA's disappearance to the arrival of DOLITTLE. However, it's quite puzzling to learn the acquaintance between MRS HIGGINS and DOLITTLE. In the initial appearance of Act II, DOLITTLE reveals the source of information for reaching MR HIGGINS's house, but in Act V, it is surprising to note that there is no hint given about his past interactions with MRS HIGGINS's but the playwright abruptly introduces him to be at the doors of MRS HIGGINS's house.

\section{Datum, ACT V}

MRS. HIGGINS. But what has my son done to you, Mr. Doolittle?

DOOLITTLE. Done to me! Ruined me. Destroyed my happiness. Tied me up and delivered me into the hands of middle class morality.

(Shaw, [13], ACT V, P. 108-109)

In Act $\mathrm{V}$, the very moment DOLITTLE notices HIGGINS, he becomes nostalgic and when Mrs HIGGINS's enquires of his current state of disappointment, DOLITTLE expresses unpleasant feelings and holds HIGGINS responsible for elevating his status to the middle class. The expressions "ruined", "destroyed", "tied", and "delivered" indicates different parts of speech with "-ed" endings. The words "destroyed", "tied" and "delivered" are verbs while "ruined" is an adjective. The expression "middle class morality" when examined critically and related to the past life of DOLITTLE gives the readers a feeling that he was happier in the past. The accusations of DOLITTLE is also indicative of how lazy individuals, when elevated to a higher status, complain of accomplishing the current professional responsibilities and feel unhappy for being given a higher stature in society. In order to reveal a transformation in DOLITTLE's career, the playwright initially creates a sense of confusion and misunderstanding in the minds of interlocutors but also intermittently reveals the realities that remain as a surprise to other interlocutors and to the readers as well.

The dialogic expressions of DOLITTLE serve to fulfil the intentions of the playwright to evoke curiosity in the readers wherein the actions of the play through verbal exchanges between the characters provide hints about the attitude, self-image and perceptions that influence different categories of people in a society. The intensity and the choice of dialogic expressions "Oh! Drunk! am I? Mad! am I?" though quite simplistic in form and structure but quite innovative in composition reveal Bernard Shaw's literary shrewdness of making the discourse realistic and exciting for the readers. The wit in the dialogues of DOLITTLE, often highlights the realities of Victorian life and society.

\section{DISCUSSION OF FINDINGS}

\section{The relevance of Weigand's [1] theoretical principles to evaluate dialogic discourse}

In the opening lines of 'Preface to Pygmalion', George Bernard Shaw states "Pygmalion needs, not a preface, but a sequel" [13]. It coincides with the theoretical observations of Wiegand's [14] wherein she states that arguments are dependent on the speaker's perspective and to be understood as a communicative means to promote the speaker's point of view and can be judged differently by different individuals. Bernard Shaw though disagrees to the idea of a preface, progresses to present a detailed background of the reasons behind the deterioration of spoken English and the need to address this issue by the native Englishmen. After the end of Act V, the playwright adds a sequel to narrate the sequence of events that happens in the lives of Liza, Freddy, Pickering and Higgins. Bernard Shaw is of the view that after the end of Act V, the readers may predict a romantic relationship between Higgins and Liza. The playwright's intentions to control the communicative moves of the reader, though is not appreciable, leads to the inclusion of "sequel" at the end of the drama. In the sequel, Shaw presents different viewpoints that his readers may predict and makes critical observations to put forward his point of view as an acceptable ending to the story.

\section{The effectiveness of dialogic discourse to perform communicative functions such as initiation and reactive}

In Pygmalion, the dialogic exchanges between the characters make the actions of the play quite realistic, because the playwright engages the readers to absorb themselves into the meaning-making process of familiar contexts as they journey through the realities that people from different walks of life experience during the Victorian era. The initiation of a dialogue with communicative intent, sometimes quite long, as observed in DOLITTLE'S utterances, and reactive moves of other characters make the dramatic text resemble the form of spoken discourse. The dialogues composed by Bernard Shaw in Pygmalion complies to Feller [14] theory, wherein she pointed out how two different types of action, namely initiative and reactive speech act makes the dialogic discourse more meaningful. The playwright initially introduces the characters with names such as 'THE FLOWER GIRL', 'THE GENTLEMAN', and 'THE NOTE TAKER'. It deviates from the practice that people follow in their everyday life wherein the initiative move to introduce a stranger to the audience involves firstly, the real name being introduced and then a detailed description of an individual's social and professional background is presented. In real-life situations, when an individual is being introduced to the audience for the first time, it is a 
convention to present their academic and professional credentials. However, in Pygmalion, readers have to apply inferencing skills to identify the roles and responsibilities of characters because Bernard Shaw introduces them with anonymous names that are quite familiar to the readers. Bernard Shaw creates interest and suspense in the readers' mind because the urge and inquisitiveness to uncover the happenings between the characters make the readers concentrate more on their reading activity. The playwright elevates the dramatic discourse of the play to make it appealing to the readers' intellect and emotions. The tone of initiative and reactive speech acts through which the characters communicate to express their feelings and opinions enables the readers to connect with new language expressions. These expressions can be used to communicate agreement, disagreement, humour, sarcasm, anger, frustration, irony, and to reason an argument as well.

\section{The effectiveness of dialogic discourse to perform communicative functions such as verbal and non- verbal acts}

The intention of George Bernard Shaw to provide a preface and a sequel to the drama, though curtails the readers to make intelligent guesses about the past and future actions of the play, creates an awareness of different situations that the readers are likely to uncover at different stages of drama. The background context that Shaw provides in the preface functions as a link to all the five acts of the play wherein the readers' attention is drawn to the way the characters use language to express their views and feelings. The structures of the dialogic communication serve to fulfil the playwright's intentions of presenting a realistic description of the scenario in which the characters live in. These dialogic structures coincide with the views of Wigand [1] that the utterances composed by a playwright have to be situationally relevant and match the cognitive levels of the readers. The playwright skillfully integrates the behavioural patterns as well as the cockney spoken by THE FLOWER GIRL, thereby, making the discourse understandable to the readers.

Further, the physical movements and the mental state of THE NOTE TAKER during his conversation with THE FLOWER GIRL depicted in the present tense, "opens his book and holds it steadily", create a visual effect and presents the scene more livelily to the readers. The playwright's ability to describe physical movements, mental states and the actions of the characters employing simplistic language expressions makes the text relevant for ESL (English as a Second Language) classrooms. The syntactic structures of dialogic language can be a useful resource and serve as language input to the ESL/EFL students.

\section{How the playwright connects the dialogic actions of the play and makes it understandable to the readers}

The visual and auditory descriptions that the playwright depicts in the opening scene of the play guide the readers to create mental images of the scene where characters are found to be communicating due to their proximity to one another. In order to make the dialogic context clear to the readers, Bernard Shaw provides detailed information about the scene where characters communicate with each other. Shaw's approach in composing dialogues for Pygmalion is quite similar to the views of Weigand [1] wherein she states the misunderstandings that can occur in speakerlistener communicative situations can be corrected when the meaning of an utterance is understood in the context of dialogic interaction. In Act I of the play, the opening dialogue initiated by THE DAUGHTER with her mother is linked to the weather conditions. The description of the setting with dialogic language relevant to the context brings coherence to the actions of the play. The familiarity of contextual dialogues and the usage of everyday expressions such as the mother, daughter, bystander, flower girl, gentleman, and the note-taker make the discourse between these characters comprehensible to a reader. Further, the playwright skilfully integrates the dialogues to the setting wherein the characters engage in verbal exchanges on matters related to time, transport, weather conditions, geographic location, and money, giving hints to the readers of their economic status and social background.

The characters such as THE SARCASTIC BYSTANDER and THE BYSTANDERS GENERALLY, though considered being insignificant characters as their roles and appearance in the play remain temporary, but their utterances signalling their interference creates a dramatic effect due to the sarcasm. Their abrupt and unwelcoming utterances also pave the way in aggravating the misunderstanding between the main characters of the play. The usage of everyday expressions such as "business", "promotion" "shelter" "insulted" revealing the anger of a bystander makes the ESL/EFL readers visualise the scene and connect it to real-life situations. In the opening scene of the play, the playwright creates suspense by concealing the identity of the characters with anonymous names such as notetaker, flower girl and gentleman and as the actions of the play progress; the readers get to know the real names of the main characters as Higgins, Pickering and Liza. The concealment of the names serves as a strategy to make the readers curious about the dialogues that follow, thereby creating more interest to uncover the later developments in the play.

In the opening scene of Act V, the playwright ends the suspense created at the end of Act IV with the sudden disappearance of LIZA from the home of HIGGINS. The playwright brings all the main characters of the play together to MRS HIGGINS' house, and the discourse between these characters highlight the ordeals of DOTLITTLE and LIZA after their transformation to higher stature in the society. 
DOLITTLE and LIZA accuse Prof. Higgins of his interference in transforming their lives. The father and the daughter accuse Prof. Higgins responsible for unwanted interference in their personal lives. The English lessons that LIZA learnt elevated her status in society, but she feels that it has increased her misery. On the other hand, DOLITTLE's feels that undue importance is given to his stature also gave rise to challenging situations due to which he struggles to keep up the expectations of the society. The phonetic lessons that LIZA learnt from Prof. Higgins and the "silly joke" in the letter written to Ezra D. Wannafeller that DOLITTLE as the "most original moralist at present in England", again by Prof. Higgns, though a positive aspect to be appreciated, makes their career path quite challenging. The playwright skillfully composes the dialogues by integrating the behavioural patterns and the spoken discourse of LIZA. DOLITTLE is introduced initially in Act II, and then again in Act V. In Act $\mathrm{V}$, he is found voicing out his protest about a reference of his name to the letter written to Ezra D.Wannafeller by Prof. Higgins. It links the thematic context of the play, revealing how a casual remark on a written script by eminent personalities in the society can change the fate of an individual.

\section{The suitability of syntactic structures in the dialogues to enhance English language skills of ESL students}

In Pygmalion, the dialogic structures with unusual word order make the discourse impressive to the readers. These structures can be a source of language input to the ESL undergraduates. In addition to the contextual meaning within the text, the dialogues scripted in Pygmalion can be a useful resource for interactive sessions in the classrooms. As pointed out by Weigand [17], speech acts expect readers to apply their critical thinking skills to comprehend and analyse the underlying meanings of dialogic language. In order to intensify the actions of the play and create an impact on the readers' mind, George Bernard Shaw uses words such as "creature", "claws" "cat". The syntactic structures presented in the form of dialogues in Pygmalion can be used by ESL/EFL teachers to create classroom activities such as lexical sets and other vocabulary related communicative activities through which students can be trained to generate appropriate and meaningful sentences. However, in most of the colleges across the Telangana region, the study of Pygmalion is limited to the specialised English language courses and remains unexplored by science and engineering students.

\section{How to explore the linguistic aspects of dialogic language}

In Pygmalion, an analysis of the dialogic exchanges between the characters of the play informs the readers about how various sections of people during the Victorian era used English to express their opinions and feelings. The structural patterns of the dialogic utterances with their semantic effectiveness communicate vivid realities of different sections of people living in contemporary society. In order to familiarise the setting of the play, the playwright prefers to familiar expressions such as "THE NOTE TAKER", "THE FLOWER GIRL" and "THE GENTLEMAN" and also creates an atmosphere of anonymity before revealing the real names these characters to the readers. However, the familiarity in common names makes the utterances of the characters comprehensible to the readers. Most of the utterances in the play have the potential for different interpretations and therefore can be resourceful for classroom discussions in ESL/EFL classrooms. ESL/EFL teachers can also use selective dialogues to promote classroom interaction among the students. Since these dialogues are composed of words paving the way for appropriate syntactic structures at sentence level, it can be a source of language input for ESL/EFL students because they have the potential for creative interpretations using the target language. The logic and reasoning in the arguments and exchanges of the characters often seem to have an auditory effect due to the use of non-verbal cues as well as its intensity to convey the intended idea precisely to the readers. The revelation of uneasiness, anger, anxiety, frustration, criticism, provocation in the dialogic language makes the readers empathise and sympathize with the characters.

\section{CONCLUSION}

The insights based on linguistic analysis of Pygmalion presented in this paper can be a model for other researchers in the interdisciplinary fields of language and literature to apply similar approaches to analyse literary texts. Also, the analysis of syntactic structures to derive underlying meanings and identify grammatical categories of words can be a resourceful input for ESL teachers to follow similar techniques while discussing literary texts in ESL classrooms. As mentioned earlier in the limitations of the study, George Bernard Shaw's Pygmalion is a drama with creative expressions and has the potential for thematic and linguistic interpretations. In the past, many researchers have contributed articles in the thematic analysis of Pygmalion while this paper approached the play from a linguistic viewpoint and provided insights for other researchers in the field.

\section{REFERENCE}

1. Weigand, E. (2009). Language as dialogue: From rules to principles (S. Feller, Ed.). Amsterdam: Benjamins.

2. Anugerahwati, M. (2010). Pygmalion: A Study of Socio-Semantics. TEFLIN Journal,21(2), 201-210. Retrieved April 23, 2019.

3. Chen, L. (2006). A Feminist Perspective to Pygmalion. Canadian Social Science,2(2), 41-44. Retrieved April 24, 2019.

4. Cherlin, C., \& Abilasha, R. (2018). Feministic Perspective in George Bernard Shaw's 
Pygmalion. International Journal of English Language, Literature in Humanities, (Special Issue - Publication of Conference Proceedings), 223228.

5. Reynolds, J. (2016). Shaw's Pygmalion: The Play's the Thing. JSTOR,36(2), 238-255. Retrieved May 12, 2019.

6. Gadhiraju, C. (2017). Myths of creation: A study of George Bernard Shaw's Pygmalion. International Journal of Advanced Education and Research,2(2), 64-66. Retrieved May 13, 2019.

7. Xiaowei, Z. (2018). A Study on Feminism of George Bernard Shaw's Pygmalion. Studies in Literature and Language,17(3), 6-9. Retrieved May 13, 2019.

8. Gupta, P., \& Mahajan, P. (2015). The Recreation of Archetypal Pygmalion in George Bernard Shaw's "Pygmalion". International Journal of English Language, Literature and Translation Studies, 2(2), 242-244. Retrieved May 13, 2019.

9. Gallardo, B. C. (2001). "Why can't women talk like a man?": An investigation of gender in the play Pygmalion by Bernard Shaw. Retrieved June 10, 2019, from https://core.ac.uk/download/pdf/30361303.pdf

10. .Shenbagapriya, K., \& Jemeena, J. (2018, December 22). Problems and emotions in Pygmalion by Bernard Shaw. Retrieved June 13, 2019, from
11. Hamoud, A. M. (2019). The use of the Concept of "Language Variation" As a Stylistic Device in Pygmalion: Toward Socio-Stylistic Approach. International Journal of English Linguistics, 9(5), 422-429.

12. Nalliveettil, G. M., \& Mohamed, M. S. (2016). Discourse Analysis of Tennessee Williams' "The Glass Menagerie". Advances in Language and Literary Studies, 7(3), 201-210

13. Shaw, G. B. (2018). Pygmalion (Reprint 2018). New Delhi, India: Prakash Books India Pvt Ltd.

14. Feller, S. (2009). Introduction: In the tide of change. In Language as Dialogue: From rules to principles of probability. Amsterdam/Philadelphia: John Benjamins Publishing Company, 5:5-11

15. Mayer, L. R. (n.d.). A Teacher's Guide to the Signet Classics Edition of George Bernard Shaw's Pygmalion. Retrieved December 28, 2019, from https://www.penguin.com/static/pdf/teachersguides /Pygmalion.pdf.

16. Weintraub, S., \& Stewart, J. I. (n.d.). George Bernard Shaw. Retrieved June 13, 2019, from https://www.britannica.com/biography/GeorgeBernard-Shaw/images-videos

17. Pirnajmuddin, H., \& Arani, F. S. (2011). Discourse and Power in George Bernard Shaw's Pygmalion. Studies in Literature and Language, 3(3), 146-152. Retrieved April 25, 2019. 